\title{
THE EVOLUTION OF THE SO-CALLED PROVINCIAL LAW, OR: CICERO'S LETTERS OF RECOMMENDATION AND PRIVATE INTERNATIONAL LAW IN THE ROMAN WORLD*
}

\author{
Hannah M. Cotton
}

The sub-title to this paper, "Cicero's Letters of Recommendation and Private International Law in the Roman World", combines two pieces of autobiography. My unpublished doctorate was devoted to Latin letters of recommendation by Cicero, Pliny the younger and Fronto. ${ }^{1}$ It was much later that, quite by chance, I came across the concept of Private International Law and realized that it could be applied to the Roman Provincial scene, exploring this for the first time in a paper delivered in 2005 in a conference in honour of Professor Werner Eck. As befitted the honorand, this concentrated on the "High Empire". ${ }^{2}$ It was only recently that I have come to see that the concept could be usefully applied to the early imperial period as well, the Republican Empire so to speak.

I. The letter of recommendation - litterae commendaticiae as it is called in the Ciceronian Corpus ${ }^{3}$ - is by no means an exciting literary genre; nor are the formulae and the attempts to manipulate and challenge them so as to distinguish between routine and mechanical letters of recommendation and the unusual one which is meant in earnest, particularly arousing, nor do they ever surprise. Nevertheless these formulae are sometimes quite useful: I got into the habit of ending my letters of recommendation

* I am very grateful to Stéphane Benoist for his inexhaustible patience, and to Nicholas Horsfall and Alexander Yakobson for improving my text and my arguments.

1 H.M. Cotton, 'Letters of recommendation: Cicero-Fronto', unpublished DPhil. Dissertation, University of Oxford, 1977, supervised by Professor Sir Fergus Millar.

2 It was published as 'Private International Law or Conflicts of Laws: Reflections on Roman Provincial Jurisdiction', in R. Haensch et J. Heinrichs (eds.), Herrschen und Verwalten. Der Alltag der römischen Administration in der Hohen Kaizerzeit (Köln 2007), 234-255.

${ }^{3}$ Fam. 13.26.3 with H.M. Cotton, 'Cicero, Ad Familiares XIII 26 and 28: Evidence for Revocatio or Reiectio Romae/Romam', Journal of Roman Studies 69 (1979), 48-50. See however P.Mich. 8.468, col. II 1l. 39-40 with H.M. Cotton, Documentary Letters of Recommendation in Latin from the Roman Empire (Beiträge zur klassischen Philologie Heft 132), (Königstein/ Ts. 1982), 1 ff. and S. Strassi, L'archivio di Claudius Tiberianus da Karanis (Archiv für Papyrusforschung und verwandte Gebiete 26) (Berlin-New York 2008), 178-179. 
for outstanding students with a variation on Cicero's formula in a letter to Caesar (Fam. 13.15.3): genere novo sum litterarum ad te usus ut intellegeres non vulgarem esse commendationem.

However, their interest for me had nothing to do with any theory of genre. Cicero's letters of recommendation are mostly appeals to Roman officials in the provinces on behalf of people whose interests fell within the officials' sphere of competence (imperium; potestas). Yet surprisingly the letters often fail to refer to the official authority vested in the recipient, and this paucity of references to it contrasts sharply with the multitude of appeals to the man's humanitas, liberalitas, uoluntas, integritas, mansuetudo, clementia, studium, officium, etc. These are all patently personal qualities, not derived from the man's official position. Likewise few recommendations explicitly ask for an official act on the part of the addressee. Generally they are requests to extend his friendship (fides, amicitia, necessitudo and similar terms) to the person or persons recommended.

Where the vagueness and obscurity characteristic of such letters resolves to some detail, a matter of litigation or legal dispute is generally at hand. This is hardly a cause for surprise. Jurisdiction, after all, was the main duty of the governor in a peaceful province. It is precisely because these letters contain appeals to officials in matters concerning the latter's judicial competence that they may justly be held to reflect Roman attitudes towards the administration of justice in their empire. One is surely entitled to suspect, if not condemn, these letters, as blatant attempts to flout justice and make gratia, personal influence, tilt the balance in favour of a protégé. Or as J.M. Kelly put it in a nutshell: "are not justice and favour mutually exclusive ideas, even in Latin?" Consequently he dismissed the saving clause, usual in such letters, "so far as your dignity and justice will permit", as a stock phrase, "which probably meant as little to the recipient as to the sender, as the broad wink of gratia passed between them". 4 I have tried to save Cicero's reputation in an analysis of the realities and principles underpinning Roman provincial administration of justice. ${ }^{5}$ David Daube was left unconvinced by what, in a private communication, he described as "special pleading", meaning sophistry, perhaps naïveté.

4 J.M. Kelly, Roman Litigation (Oxford 1966), 58 and 61.

5 H.M. Cotton, 'The Role of Cicero's Letters of Recommendation: Iustitia versus Gratia', Hermes 114 (1986), 443-46o. 
My main line of defence was that these letters fulfilled an essential function in a system of government, which left the governor with wide discretionary powers on the one hand, and on the other without the machinery needed to carry out judicial and administrative transactions on a regular and impersonal basis. Hence we may regard these letters as part and parcel of the Roman political system as opposed to the ancillary role, which they have in modern bureaucracy. ${ }^{6}$ I also suggested that there were other safeguards, such as the need to preserve decorum on the recommender's part, and to protect his own existimatio on the governor's. Finally, I supplied plenty of extenuating circumstances. I claimed that the legal disputes mentioned in these letters do not necessarily imply court proceedings, and that more often than not Cicero's letter is aimed at something quite different than obtaining the governor's favour at the trial stage. Hence these letters should not be seen as attempts to bias the judge and influence the verdict itself. Furthermore, court proceedings were distasteful to the Romans and they tried to avoid them: the recommendation was one way of doing so. This may take the form of a direct appeal to prevent litigation, as Cicero does in the case of his translator's son's mother in-law: Q. Minucius Thermus proconsul in Asia in 50 BC is requested to help and bring about ut socrus adulescentis rea ne fiat (Fam. 13.54). On other occasions the governor's influence is enlisted as an alternative to legal remedies, i.e. to induce the other party to settle out of court (we are not told whose court of law: the governor's or a local court?). For example P. Silius, governor of Pontus-Bithynia in $5^{\circ} \mathrm{BC}$ is asked to urge the Greek cities to conclude their pactiones with the promagister of the public company which collects the scriptura in the province, P. Terentius Hispo (Fam. 13.65). ${ }^{7}$ In the case of the succession of Cicero's former quaestor, L. Mescinius Rufus, to the inheritance left to him by his cousin, M. Mindius, Servius Sulpicius Rufus, governor of Achaia in 46 вС (Fam. 13.26) is requested to threaten Mindius' widow, Oppia, with a remittal of the case to Rome as means of swiftly concluding the affair, presumably out of court. ${ }^{8}$ An expeditious solution is desired in the case of Cicero's legate, whose services are indispensable to his superior (Fam. 13.57.1). If legal proceedings have already begun by the governor, Thermus, we may

\footnotetext{
${ }^{6}$ For its survival into the imperial period see H.M. Cotton, 'Military Tribunates and the Exercise of Patronage', Chiron 11 (1981), 229-238.

7 H.M. Cotton, 'A Note on the Organization of Tax-Farming in Asia Minor (Cicero, Fam. 13. 65)', Latomus 45 (1986), 367-373.

8 Cotton 1979, op. cit. (n. 3).
} 
assume that Cicero attempts to prevent them from dragging on, but he could be asking for a swift solution out of court. Finally, in his recommendation of T. Claudius Nero's protégé Pausanias of Alabanda, Cicero is trying to convince Silius that he should delay legal proceedings pending Nero's arrival (Fam. 13.64.1). ${ }^{9}$

When Cicero requested a governor to refrain from action, he was not denying anyone his right - at least this is not how the Romans would have seen it. For it is well known that classical law never formulated any idea of an individual's right to an action. The presence of an actio does not necessarily imply that the man had a claim, but rather that there was a formula that could be adapted to his case, and the formula was a matter of agreement between the praetor (governor) and the two parties. This was another way in which the governor could, if he chose, remain passive without, however, depriving anyone of an inherent right.

Some letters have a prophylactic and provisory nature, as in the case of L. Genucilius Rufus, where Cicero requests Thermus to hear in the assize centre of the area any dispute which might arise in the future between this man and a provincial (Fam. 13.53.2). Similarly in the case of L. Manlius who inherited his brother's estate in Sicily, although no complications were foreseen at the time, it may safely be assumed that the recommendation was intended to provide for such an eventuality (Fam. 13.30). The same may be said about the recommendation of Lyso's son's right to inherit from the Roman exile, C. Maenius Gemellus, who adopted the young man in accordance with the local laws of Patrae (Fam. 13.19.2). The last two cases have a bearing on the issue of 'double citizenship', which will be discussed later.

The variety of the requests surveyed here suggests a corresponding variety of means at the disposal of the governor. Whether these putative means are to be called judicial, administrative, extra-judicial, authoritative, or by any other name is often a matter of definition. These letters call on the governor to employ his discretion in the preliminaries, the procedure, the pace of the proceedings and so forth. Interference in these, as it might be, 'phases' clearly implies that the discretion of the governor was

9 For an imperial example of the delicate interplay between the governor's discretionary powers, the rights of cities and the influence of individuals see Ch. Kokkinia, 'Aphrodisias's "rights of liberty": diplomatic strategies and the Roman governor', in Chr. Ratté and R.R.R. Smith (eds.), Aphrodisias Papers 4. New research on the city and its monuments (Portsmouth, Rhode Island 2008), 51-60. 
wide, the system was flexible, and the use of discretion need not entail a reversal of justice, to go back to Kelly's doubts (above text to n. 4).

Although I have never published my doctoral dissertation but merely despoiled and looted it in a few articles, my interest in administration and jurisdiction - inseparable in ancient governments - remained a lifetime preoccupation.

However, as one sheds one's youth, the 'noble' principles governing a legal system seem to matter less than its operation: wie es eigentlich gewesen ist. And this new phase coincided by a happy serendipity with the re-distribution in 1992 of the documents from the Judaean Desert by the Advisory Committee for the Dead Sea Scrolls of the Israel Antiquities Authority, some of which now turned up, so to speak, on my desk, and invited me to the study of case law. I was back where I had started, but now equipped with authentic documents from real life - not that the letters assembled in Book 13 of the Ad Familiares are not authentic: they may have been published already in Cicero's own lifetime. ${ }^{10}$ However, this time I had documents written by the litigants themselves, or their lawyers, and in some cases the protocol of court proceedings. I was admitted into the ancient courtroom.

II. This is where my second topic, private international law, or 'conflict of laws' enters the scene, and it seems necessary at this point to repeat here almost verbatim my introduction to the topic in the earlier article. ${ }^{11}$

I became acquainted with private international law almost by accident when one day my eyes fell on the opening anecdote in an article by a close friend, who is a well-known expert on the subject. ${ }^{12}$ The expression 'private international law' suggests at first sight - quite wrongly as turns out - that there are two kinds of international law, private and public. But in fact 'private international law' does not mean 'international law' in the sense of a law common to all nations, but rather that part of the national law of a country which deals with cases where a foreign element intrudes in one form or another: e.g. one side to the contract or suit is a foreigner; or when the property in question is outside the country where the court

10 L. Gurlitt, 'De M. Tulli Ciceronis Epistulis Earumque Pristina Collectione', Diss. Göttingen, 1879 .

11 Cotton, op. cit. (n. 3), 234-235.

12 C. Wasserstein Fassberg, 'On Time and Place in Choice of Law for Property', International and Comparative Law Quarterly $5^{1}$ (2002), 386-400, to whom I wish to thank for letting me read the general introduction to her forthcoming book, in Hebrew, on the subject. 
operates; or if the contract is signed in a third country; or when all these and other factors come together - with many other variations. It is that set of rules which deals with what are known as 'conflicts of laws', although its purpose is to resolve rather than to analyse the conflicts between legal systems. Thus both terms, private international law and conflicts of laws, are to a certain extent misnomers.

Broadly speaking, cases of conflict of laws revolve around two issues: 1) which court has jurisdiction in the matter; and 2) what law applies. It does not follow automatically - nor would it be fair and just that it should - that the court which has jurisdiction in the matter, will apply its own law. A third but closely related issue is the enforcement of a judgement of a foreign court by the national court. Finally, there is no 'harmony of laws' between private international laws of different countries, i.e. in the rules concerning conflicts of law - perhaps it is not even so desirable or beneficial to achieve such harmony.

Notwithstanding the reservation of one of the foremost authorities on the subject, ${ }^{13}$ I believe that it is both legitimate and profitable to apply the conceptual framework called forth by private international law to the Roman Empire as early as republican times, even if is it true that local legal institutions owed their continued existence and their regulation to Roman toleration of their existence. On the other hand, nowhere do we witness that Rome, once she became the sovereign, tried to impose her own legal system, her own law and jurisdiction on the subject populations: ${ }^{14}$ the ius civile was intended for cives; at most Rome extended to foreigners some provisions of its ius civile (e.g. by using the fiction si ciuis Romanus esset). Wolff's argument that 'private international law can only establish itself where respect is shown for foreign law', which he takes to be the sine qua non for the development of private international law, is untenable.

13 H.J. Wolff, 'Nicht Gleichordnung, sondern Über- und Unterordnung bestimmte die Stellung der Normenkreise zu einander', in Das Problem der Konkurrenz von Rechtsordnungen in der Antike (Heidelberg 1979), 7 and 66. I thank Professor Lucia Fanizza for discussing the issue with me, and drawing my attention to some pertinent bibliography. See also Hans Lewald's 'Conflits de lois dans le monde grec et romain', published for the first

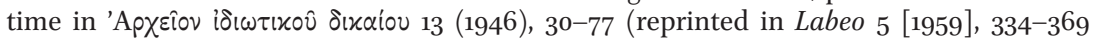
and Revue critique de droit international privé 57 [1968], 419-440 and 615-639), for an early systematic attempt to analyse the legal evidence from the Graeco-Roman world from the point of view of 'private international law' or 'conflict of laws'.

${ }^{14}$ H. Galsterer, 'Roman Law in the Provinces: Some Problems of Transmission', in M. Crawford (ed.), L'Impero Romano e le Strutture economiche e sociali delle Province (Como 1986), 13-27. 
Theoretically, with the exception of some communities who had a special treaty with Rome, all of Rome's provincial subjects were de iure under the jurisdiction (iuris dictio) of Roman officials. However, judicial autonomy, that is the use of local courts of law and of local law, especially in civil cases, may well have been taken for granted, or at least need not have called for a specific grant by the Roman government - at any rate in the case of self-governing communities, i.e. cities. Later, it seems to have become a tralatician part of the provincial edict, as we know from Cicero's provincial edict in Cilicia where he was governor in $50 \mathrm{BC}$ (Cic. Att. 6.1.15), and it is this wholesale, perhaps formerly implicit, grant of local autonomy, that introduced 'conflict of laws' into the scene; no more than the tacit admission of the foreign in legal contexts is needed for the private international law to become part and parcel of a legal system. The legal situation prevailing in Sicily as described by Cicero (2Verr. 2.31-32) adumbrated regulations which modern jurists would have recognised as belonging to the sphere of 'private international law' or 'conflict of laws', as does Augustus' fourth Cyrene edict (FIRA I' ${ }^{2}, 68$, p. 409). It is remarkable that with the exception of cases between citizens of the same city in Sicily who are to be tried suis legibus in the city's court, both Cicero and Augustus only refer to courts, i.e. the jurisdiction, but fail to specify the law to be exercised in the court. However, the principle of 'inalienability' of personal legal status (see more below) taken together with the absence of any sign for the imposition of a single juridical framework for the whole empire, ${ }^{15}$ renders the question of the extent of local legal autonomy of secondary importance: limited and curtailed though local jurisdiction might have been, peregrines continued to enjoy the use of their personal law either in their own courts or in those provided by the Romans. A man could not have a choice between the personal laws of one legal system and another. ${ }^{16}$ In republican times, the question concerned Roman citizens living in the provinces but even more so newly made citizens, those who certainly after 212, but also before, received the citizenship with the rider saluo iure gentis. True, with the spread of citizenship and the rapid increase in the number of mixed communities, civitas, citizenship, did change its character, but so far as personal law was concerned, it is hard to believe that the principle enunciated by Cicero in the Pro Balbo 28 suffered any derogation: Duarum ciuitatum ciuis noster esse iure ciuili

15 See Galsterer 1986, op. cit. (n. 14).

16 See on "double citizenship" below. 
nemo potest: non esse huius ciuitatis qui se alii ciuitati dicarit potest. The restriction implied by saluo iure gentis did not apply to personal status: it inserted a wedge between public duties and private status. The possession of Roman citizenship was inextricably bound up with the ius civile in matters concerning the law of persons, and denotes personal status in contrast to public duties. ${ }^{17}$

This is why one can, or rather should, look at these cases through the prism of the principles underlying modern Private International Law, which as we saw were not unknown, even if never formulated as such, in the Roman World. ${ }^{18}$

III. It is my intention to discuss a few cases taken from Cicero's letters of recommendation to republican provincial governors. A good starting point would be Cicero's letter to M. Acilius Glabrio, governor of Sicily in 46-45 BC (Fam. 13.30), where one witnesses the kind of 'conflict of laws' resulting from the acquisition of Roman citizenship by one member of the peregrine family: ${ }^{19}$ "L. Manlius Sosis was formerly a citizen of Catina. He became eligible for Roman citizenship together with the rest of the Neapolitans, since his attachment to that town had preceded the grant of franchise to aliens and Latins. He also served as a town councillor there."20

17 Cf. A.N. Sherwin-White, The Roman Citizenship ${ }^{2}$ (Oxford 1973), 273: 'in the second century $[\mathrm{CE}]$ the status of a Roman citizen was, in private law, as clearly fixed and defined as ever it had been'.

18 One should take account now of the first two chapters of Clifford Ando, Law, Language, and Empire in the Roman Tradition. Empire and After (Philadelphia 2011). As the reader of the present volume will realize, the themes raised in the present article intersect with his "Pluralisme juridique et intégration de l'empire". I would subscribe to all the conclusions reached and summarized at the end of his article, but use his own words to insist: "sur le caractère à la fois centripète et centrifuge de ces pressions intégratrices, qui s'exerçaient non seulement d'en haut mais aussi d'en bas" (emphasis mine). For a salient example of the latter see T.J. Chiusi, 'Zur Vormundschaft der Mutter', ZSav 111 (1994), 155196 and Ead., 'Babatha vs. the Guardians of her Son: A Struggle for Trusteeship - Legal And Practical Aspects of P. Yadin 12-15, 27', in R. Katzoff and D.M. Schaps (eds.), Law in the Documents from the Judean Desert (Leiden 2005), $105 \mathrm{ff}$. In both she demonstrates the legal measures proposed by Babatha (or rather, her lawyer) in the document to support resurface in third-century Roman legal writings.

19 For imperial examples and their interpretation see F. Millar, The Emperor in the Roman World (London 1977), 484, referring to Pliny, Pan. 37-40.

20 Is fuit Catinensis, sed est una cum reliquis Neapolitanis ciuis Romanus factus decurioque Neapoli; erat enim adscriptus in id municipium ante ciuitatem sociis et Latinis datam. Unlike the poet Archias, who was a non-resident adscriptus of Heraclea, L. Manlius Sosis did reside in his adoptive patria, namely Naples, and became a citizen under the lex Iulia: see Sherwin White 1973, op. cit. (n. 17), 151-152, on this letter in conjunction with Cicero, Pro Archia 7. 
His brother had recently died at Catina, but Cicero did not expect any dispute to arise over his title to the estate, and indeed he was in possession of it at the time the letter was written:

However, since he has some old affairs of business in his part of Sicily, I beg to recommend to your notice this matter of his brother's estate and all other concerns of his, above all the man himself. He is an excellent person and a familiar friend of mine, conversant with the literary and scholarly pursuits in which I chiefly delight. Let me ask you (whether or not he goes to Sicily) to be aware that he is one of my closest and most intimate friends, and to let him understand by the way you treat him that my recommendation has been of substantial assistance to him. ${ }^{21}$

Cicero stresses that no dispute is hanging over the inheritance (nullam omnino arbitramur de ea hereditate controuersiam eum habiturum), and under Roman law the fact that "he is in possession" - est hodie in bonis means that "if anyone wishes to disturb (it) ... he can only do so by means of a regular judicial proceeding in which he himself proves a title". ${ }^{22} \mathrm{How}-$ ever, if a dispute arose, could a remedy be sought under Roman law? The testament, if it was a testate succession, or the remedies, if it was an intestate succession, would have been in both cases foreign instruments, and, as pointed out before (text to nn. 16 and 17 above), it is inconceivable that a Roman citizen could inherit (as well as disinherit, or marry, divorce, bequeath, adopt, etc.) according to one system or another, depending on the prospective jurisdiction, in accordance with his own free choice. L. Manlius was subject by the principle of personality to one legal system whereas his inheritance fell under another. How could he have realized it if a dispute arose, and which court of law would take cognizance of the case, a Roman court or a local court? This is a perfect case to which in modern times we would look for the provisions laid down by the private international law of each one of the two countries involved, which may or may not be in harmony with each other, e.g. one law may refer to the lex situs whereas the other to the personal law of the parties involved. ${ }^{23}$

21 sed, quoniam habet praeterea negotia uetera in Sicilia tua, et hanc hereditatem fraternam et omnia eius tibi commendo in primisque ipsum, uirum optimum mihique familiarissimum, iis studiis litterarum doctrinaeque praeditum, quibus ego maxime delector. Peto igitur abs te, ut eum, siue aderit siue non uenerit in Siciliam, in meis intimis maximeque necessariis scias esse itaque tractes, ut intelligat meam sibi commendationem magno adiumento fuisse. Shackleton Bailey's translation in the Penguin edition (1978).

22 H.F. Jolowicz and B. Nicholas, A Historical Introduction to the Study of Roman Law ${ }^{3}$ (Cambridge 1972), 259.

23 See Fassberg 2002, op. cit. (n. 12). 
In contrast to this case, the adoption of Lyso of Patrae's son by C. Maenius Gemellus (Fam. 13.19), ${ }^{24}$ attracted the attention of modern jurists who dealt with the implications of the possession of 'dual citizenship'. It became a bone of contention between them, and thus received two mutually exclusive interpretations.

During the civil wars, C. Maenius Gemellus received the local citizenship of the city of Patrae where he spent his exile. As a citizen of Patrae he adopted Lyso's son in accordance with local law: [tibi commendo] filium eius (i.e. Pisonis) quem C. Maenius Gemellus, cliens meus, quum in calamitate exsilii sui Patrensis ciuis factus esset, Patrensium legibus adoptauit (ibid. \$3). Cicero requests from the governor of Achaia at the time, the celebrated jurist, S. Sulpicius Rufus, to take care of the adopted son's claims to the heritage: eius ipsius hereditatis ius causamque tuear.

Loyal to the principle of incompatibility, Arangio-Ruiz maintained that C. Maenius Gemellus, having returned to Rome after his exile, by regaining his Roman citizenship must have lost his Patrensian citizenship - at least so far as the Romans were concerned - and this resulted in the invalidation of the adoption made in accordance with the local law of Patrae: "e non sappiamo se la grande abilità di un Servio bastasse a venire a capo". ${ }^{25}$ Schönbauer seizes triumphantly on this note of despair in his rival to assert that if one accepts the principles propounded by ArangioRuiz, Cicero's appeal to Servius would be futile: "Ciceros Ersuchen wäre einfach unverständlich, wenn es keine Möglichkeit der Erfullung seines Wunsches gab". ${ }^{26}$ Accordingly he suggests that Gemellus should be treated as a citizen of Patrae who had just received (or been awarded) the Roman citizenship, rather than as a citizen of Patrae who had once held Roman citizenship and had lost it until regaining it, postliminio, when permitted to return to Italy; only in the first case, that of a newly-made Roman citizen, would legal transactions performed in accordance with the laws of his previous polis have remained valid after his having received Roman citizenship. ${ }^{27}$

24 This letter written in $46 \mathrm{BC}$, like others written after the civil war, adumbrates the advent of a new era: a third party intrudes into the egalitarian relationship between recommender and recipient, that of the dictator, whose good will must be secured in advance, see Cotton 1977, op. cit. (n. 1), chapter 4.

25 V. Arangio-Ruiz, 'Sul problema della doppia cittadinanza nella repubblica nell' impero', in Scritti giuridici in onore di F. Canelutti (Padova 1950) IV, 59-77.

26 E. Schönbauer, 'Zur Entwicklung des "ius publice respondendi”', Iura 4 (1953), 227234 (reply to V. Arangio Ruiz 1950, op. cit. [n. 25]).

27 Schönbauer 1953, op. cit. (n. 26), 393-394. However, even F. De Visscher, who generally shares Schönbauer's views on the principle of double citizenship, holds that compatibility 
Be this as it may, Schönbauer is quite right to observe (n. 27) that it was obviously too early, in any case, for 'positive norms' to have emerged. I would even go further and claim that the very attempt to detect such norms is probably misconceived: by that time the Roman State (whatever we may mean by that) could hardly have formulated principles and made provisions to close the gap between the new reality and traditional theory and practice; under these circumstances the wide discretionary powers of the governor could legitimately be called upon (see text to nn. 4-6 above).

Furthermore: it would seem that even in cases where norms did exist, the concrete evidence we have in Cicero's letters of recommendation does not unequivocally imply that they were followed. Thus in Fam. 13.37, also addressed to the governor of Sicily at the time, M. Acilius, Cicero recommends Hippias, son of Philoxenus, from the city of Calacte, "whose property ... is being held by the state under a different name in violation of the laws of Calacte". 28

This is an instance of a dispute between a private citizen and a city. The Lex Rupilia provides for such a case: "When an individual sues a community or a community sues an individual, the Council of some city is appointed to try the case, each party being entitled to challenge one council thus proposed" (Loeb translation). ${ }^{29}$ Why was the governor's assistance sought when the law (of procedure) was unambiguous? Is the governor expected merely to enforce those provisions, or accelerate the process or should we detect here an appeal for 'illegal' intervention? The cautious and courteous language suggests to me that Cicero was aware of the existence of norms, which did not permit a specific request which might compromise the governor's integrity (existimatio); he could ask only what was commensurate with the latter: Id si ita est, etiam sine mea commendatione

applied only as long as the newly made citizen remained in his home-town, whereas a mutatio ciuitatis would have resulted in its loss, see 'La dualité des droits de cité et la Mutatio Civitatis', Bulletin de l'Acad. Royale de Belgique, 5e sér., 40 (1954), 49; see SherwinWhite 1973, op. cit. (n. 17), 292-336.

The assumption shared by both Schönbauer and Arangio-Ruiz, that C. Maenius Gemellus returned to Rome, albeit reasonable, cannot be proved; it may be based on his being described by Cicero as cliens meus - a designation rarely used in Cicero's letters of recommendations, but which may well imply physical closeness. Nevertheless, C. Maenius Gemellus could hardly be the moving force behind this recommendation which is devoted entirely to promoting Piso's interests and his household's.

28 Hippiam, Philoxenifilium, Calactinum ... tibi commendo ... eius bona, quem ad modum ad me delata res est, publice possidentur alieno nomine contra leges Calactinorum.

${ }^{29}$ quod priuatus a populo petit aut populus a priuata, senatus ex aliqua ciuitate qui iudicet datur, cum alternae ciuitates reiectae sunt. (2Verr. 2.13.32). 
ab aequitate tua res ipsa impetrare debet ut ei subuenias, and later on: tantumque ei commodes in hac re et in ceteris quantum tua fides dignitasque patietur. ${ }^{30}$

I shall conclude this survey with the case of Pausanias, a citizen of the free city of Alabanda ${ }^{31}$ in the province of Asia, ${ }^{32}$ which Cicero, acting for the patrician T. Claudius Nero, brings to the attention of the governor of the province of Bithynia, P. Silius Nerva, in 50 BC: de Pausania Alabandensi sustentes rem, dum Nero ueniat (Fam.13.64.1). Is Pausanias on trial before the governor, who could be requested to delay the case, or is it a request to interfere unofficially in legal proceedings held before another court? Be that as it may, I would suggest that the question as to what legal procedure was available in the case of a citizen of a free city sojourning in another province, would certainly have taxed the skills of a modern expert on private international law. In the Roman Empire, I would maintain, it meant that legal cases tended to gravitate towards the Roman courts, which would account for the long queues and the long delays attested in our sources. ${ }^{33}$ Needless to say, this was not the sole reason for resort to the governor's court: Roman justice was more effective and could be more rigorously imposed on the antagonists. Consequently, even cases calling for the recourse to personal law may come before the governor, who could apply local law, as in the famous 'Complaint of Dionysia' (P.Oxy. 237, AD 186), or failing that, Roman civil law, as in P.Oxy. $706 .^{34}$

The foregoing discussion has by no means attempted to do more than skim the surface of the issues raised in it. In conclusion, I wish to emphasize where precisely there is need for re-thinking and further investigation:

30 For a full discussion of the significance of the terms used here (existimatio, aequitas, fides and dignitas) and elsewhere in letters of recommendation see examples in Cotton 1986, op. cit. (n. 5).

31 For Alabanda see Plinius, nat. 5.108.

32 Unless we accept Shackleton Bailey's conjecture that "the heading is wrong and that this letter was really addressed to the governor of Asia", in Cicero: Epistulae ad Familiares I (Cambridge 1977), 476.

33 E.g. P. Euphr. 1, l. 7 (= SB XXII 15496, AD 245): "spending eight months in attendance at your court" (to the governor of Koile-Syria); see D. Feissel et Jean Gascou, 'Documents d'archives romains inédits du Moyen Euphrate ( $\mathrm{III}^{\mathrm{e}}$ s. après J.-C), I. Les pétitions (P. Euphr. 1 à 5)', Journal des Savants (1995), 3 ff. On the queues see above all G.P. Burton, 'Proconsuls, Assizes and the Administration of Justice under the Empire', JRS 65 (1975), 92 ff.; cf. Cotton 2007, op. cit. (n. 2), 244 ff.

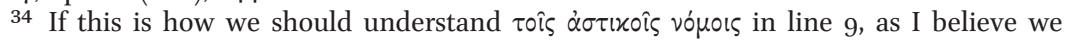
should; cf. N. Lewis, 'Nouveau Texte sur la juridicion du préfet d'Egypte', RHDE 50 (1972), 10 citing D. 1.3.32 pr. I intend to discuss this papyrus elsewhere. I am obliged to Uri Yiftach and Egbert Koops for discussing it with me. 
1) As in my earlier article (Cotton 2007, op. cit. [n. 2], passim) I would like to insist on the distinction between choice of courts and choice of law, procedure as distinct from the substance. A Roman court of law may well use and enforce local law.

2) For our purpose, the Empire could be conceived as an extension of Italy: the first 'conflicts of laws' arose and were solved when Rome entered into various treaties with the cities of Italy. Whatever rules, or rather rules of thumb, had evolved in Italy up to $90 / 89 \mathrm{BC}$, would be applied in the provinces by the very same magistrates who later on went overseas. However, the evidence for Italy is mainly epigraphic, and contains statutes rather than court cases. ${ }^{35}$

3) One cannot a-priori assume that the judicial autonomy of the more privileged communities (Roman and Latin) in a province was wider than that enjoyed by peregrine communities, which stood, so to speak, altogether outside the entire framework of the Roman legal system; the contrary may prove to be true. ${ }^{36}$

4) Above all, it seems to me, one must be fully conscious of the crucial distinction between the statutes and the law-books on the one hand and the courtroom, the litigants and the lawyers on the other. ${ }^{37} \mathrm{We}$ must, at all costs, avoid a schematic legal approach which takes legal writings as a faithful depiction of what happened in the day to day 'to and fro' of litigants and litigators: such an approach removes us from the truth, and from reality.

35 Cf. M. Crawford, Roman Statutes I-II (London 1996). Not exclusively though; for wax tablets recording legal transactions, see e.g. G. Camodeca, Tabulae Pompeianae sulpiciorum (TPSulp.) (Rome 1999) with the review article by G. Rowe in Scripta Classica Israelica 20 (2001), 225-245.

36 H.M. Cotton, 'Jewish Jurisdiction under Roman Rule: Prolegomena', in M. Labahn and J. Zangenberg (eds.), Zwischen den Reichen: Neues Testament und Römische Herrschaft. Vorträge auf der ersten Konferenz der European Association for Biblical Studies (TANZ 36) (Tübingen, 2002), $16 \mathrm{ff}$.

37 I suppose this could be summed up, perhaps anachronistically, as case law. Needless to say, legal papyri constitute our best evidence. A huge amount of work has been done, and is being done by the papyrologists, but the historians of the Roman Empire are not fully cognizant of it. 